\title{
FORM OF STANDARDIZATION AND STEREOTYPING PRACTICES THROUGH MESSAGE OF VIDEO ADS BUAVITA
}

\author{
Asnurul Novia Narendra ${ }^{1}$, Sri Kusuma Habsari ${ }^{2}$, dan Deny Tri Ardianto ${ }^{3}$ \\ ${ }^{1}$ Universitas Sebelas Maret Surakarta \\ ${ }^{2}$ Universitas Sebelas Maret Surakarta \\ ${ }^{3}$ Universitas Sebelas Maret Surakarta \\ E-mail: annarendra@student.uns.ac.id
}

\begin{abstract}
This research focuses on the symbols contained in the four Buavita video ads, namely Buavita Mix Berries, Buavita Kelapa, Buavita Mangga, and Buavita Jambu. These ad videos seem to be able to segment the community into a type of society. The research aims to prove the existence of certain symbols in the Buavita advertisement video as a practice of hegemony and perpetuating gender inequality. This research uses descriptive qualitative method with four theories of cultural studies as the theoretical basis. The results showed that Buavita's ad-style healthy lifestyle became a trick of capitalism in inviting people to consume symbols and make profits. The video presentation of Buavita's advertisement is also a medium for the perpetuation of the concept of the traditional gender role that positions women as domestic agents, passive and consumptive, while men as non-domestic, active, and productive agents.
\end{abstract}

Keywords: framework, conceptual framework, and qualitative research

\begin{abstract}
ABSTRAK
Penelitian ini fokus pada simbol yang terdapat dalam empat video iklan Buavita yaitu Buavita Mix Berries, Buavita Kelapa, Buavita Mangga, dan Buavita Jambu. Video-video iklan tersebut tampak mampu mengkotakkan masyarakat kepada sebuah jenis masyarakat. Penelitian bertujuan membuktikan adanya simbol tertentu pada video iklan Buavita sebagai praktik hegemoni dan pelanggengan gender inequality. Penelitian ini menggunakan metode deskriptif kualitatif dengan empat teori kajian budaya sebagai dasar teoritisnya. Hasil penelitian menunjukkan bahwa gaya hidup sehat ala video iklan Buavita menjadi trik kapitalisme dalam mengajak masyarakat mengkonsumsi simbol dan menghasilkan profit. Penayangan video iklan Buavita juga menjadi media pelanggengan konsep traditional gender role yang memposisikan wanita sebagai agen domestik, pasif dan konsumtif, sedangkan laki-laki sebagai agen non-domestik, aktif, dan produktif.
\end{abstract}

Kata kunci: kerangka kerja, kerangka konseptual, dan penelitian kualitatif

\section{PENDAHULUAN}

Buavita merupakan salah satu

merk minuman sari buah dalam kemasan yang telah diproduksi sejak tahun 1971 oleh Unilever Indonesia dan diluncurkan oleh PT. Ultrajaya Milk Industri tbk (Unilever, 2017). Buavita menjadi pelopor ahli minuman sari buah dalam kemasan siap santap yang menggunakan teknologi pengolahan pangan dan pengemasan yang mutakhir. Sebagai visi dan misinya, Buavita berkomitmen untuk hadir sebagai media pemerolehan nutrisi buah dan sayur bagi seluruh konsumen Buavita kapanpun dan 
dimanapun masyarakat berada dan sayur yang berbeda-beda sesuai (UnileverIndonesia, Tentang Buavita, jenisnya. Hal ini tentunya dimaksudkan 2015).

mempermudah masyarakat dalam

Buavita hadir dengan tiga jenis mengkonsumsi Buavita sesuai dengan variant rasa yaitu classic, rasa khas Nusantara, dan royale (UnileverIndonesia, Produk Buavita, 2015). Jenis rasa classic terdiri dari rasa apple, mango, lychee, orange, dan guava. Sedangkan rasa khas Nusantara terdiri dari rasa sirsak, markisa dan kelapa. Varian terakhir adalah royale yang terdiri dari sunshine carrot, mix berry dan Chloro Broccoli (UnileverIndonesia, Produk Buavita, 2015).

Buavita menggunakan iklan televisi, Youtube, dan media cetak sebagai media promosi dan pengenalan produk kepada masyarakat. Melalui iklan, Buavita mengajak pemirsanya untuk mengkonsumsi minuman tersebut sebagai minuman pendamping dalam memenuhi kebutuhan tubuh terhadap vitamin dan mineral.

Sebagai media promosi kepada masyarakatnya, perusahaan Buavita memproduksi berbagai macam video iklan dengan tema yang beragam sesuai dengan jenis/varian rasa yang dimiliki oleh Buavita. Video iklan tersebut diantaranya adalah video iklan Buavita Royal Mix Berry, Buavita Rasa Nusantara, Buavita Orange, Buavita Mango, Buavita Jambu, dan masih banyak lagi. Produser video iklan Buavita juga menampilkan video iklan dengan berbagai sugesti mengenai manfaat buah jenis kebutuhan vitaminnya.

Jika diartikan berdasarkan fungsi utama iklan yaitu sebagai media persuasif, video iklan Buavita tampak memiliki tujuan yaitu mengajak para konsumennya untuk berpola hidup sehat dengan mengkonsumsi jus Buavita yang mengandung berbagai macam vitamin dan mineral yang berasal dari buah dan sayur. Hal ini terlihat dari tagline Buavita yaitu "Minuman sari buah yang sehat untuk segala aktivitas kamu!", "Buavita, Does You Good", "Be frutarian with Buavita", tayangan-tayangan iklan, serta kalimat yang terkandung dalam video iklan Buavita yang penulis temukan baik di televisi, radio, surat kabar, majalah, Youtube, hingga poster yang tersebar di sekitar lingkungan sosial penulis.

Namun, video iklan tidak hanya hadir di masyarakat tanpa adanya tujuan implisit. Iklan sebagai salah satu produk industri budaya dipercaya mampu menjadi media yang digunakan oleh produsen dalam mengeneralisasikan rupa masyarakat. Dalam video iklan ini, khususnya yang ditujukan untuk masyarakat Indonesia, video iklan Buavita hadir tidak hanya sebagai standarisasi minuman sehat yang wajib dikonsumsi jika ingin mendapatkan tubuh yang sehat, 
namun juga standarisasi status, kewajiban, hingga tujuan utama konsumen dalam mengkonsumsi buah dan sayur yang dibedakan berdasarkan gender melalui perbedaan jenis variant rasa Buavita. Pada pengemasan video iklannya, penulis melihat bahwa produsen Buavita melibatkan standarisasi stereotype yang mengatur pembagian status, kewajiban, hingga jenis buah dan sayur yang wajib dikonsumsi oleh laki-laki ataupun perempuan melalui minuman Buavita.

Penulis melihat hal ini melalui pembedaan jenis gender aktor yang digunakan oleh produsen Buavita sebagai model dalam video iklan serta pembedaan jenis Buavita yang dikonsumsi oleh aktor tersebut. Selain daripada itu, pembedaan tampak sebagai penjelas pesan serta ideologi yang bersumber dari produsen video iklan. Tentunya hal ini tidak lepas dari konstribusi media sebagai pembuat simulasi (standarisasi) mengenai bagaimana standarisasi penampilan wanita dan laki-laki Indonesia dengan membentuk sebuah ukuran keaslian, kebenaran, serta sebuah realitas yang patut untuk ditiru dan dijalani oleh masyarakat melalui produk media (iklan) (Baudrillard, 2006:453-454). Tujuan dari dibentuknya simulasi ini tidak lain adalah keuntungan (profit) yang akan didapatkan oleh si pembuat iklan yang lagi-lagi tidak terlepas dari sentuhan kapitalis kepada sistem konsumsi masyarakat (Baudrillard, 2006:453-454).
Berdasarkan keterangan di atas, penulis terdorong untuk melihat bagaimana video iklan Buavita hadir sebagai produk media yang dipengaruhi oleh unsur-unsur kapitalisme dalam membangun simulasi standar hidup sehat dengan cara mengajak para audience-nya untuk memenuhi kodekode yang disampaikan melalui video iklan Buavita, yang tentunya melalui praktik konsumsi. Selain dari pada itu, penelitian juga ditujukan dalam melihat aturan stereotyping antara laki-laki dan perempuan melalui perbedaan jenis buah dan sayur yang terkandung dalam jus Buavita yang dapat dikonsumsi oleh konsumen laki-laki dan perempuan.

Penelitian dilengkapi dengan penggunaan metode kualitatif deskriptif dan empat teori kajian budaya yang terdiri dari pendekatan industri budaya, pendekatan stereotype, pendekatan simulasi, dan pendekatan kapitalisme guna mendapatkan hasil dari tujuan penelitian tersebut.

\section{TINJAUAN PUSTAKA}

\subsection{Industri Budaya oleh Max}

\section{Horkheimer dan Theodor W. Adorno}

Dalam artikelnya yang berjudul The Culture Industry: Englightenment as Mass Deception, Max Horkheimer beserta Adorno menegaskan bahwa zaman pencerahan yang selalu dikaitkan dengan perkembangan teknologi dan citra industri budaya yang hadir sebagai pemenuh kebutuhan masyarakat. Sebagai media, suara masyarakat hanyalah sebuah kedok 


\section{CAPTURE}

media dalam menutupi tujuan sebenarnya industri (bisnis) ideologi yang terbentuk dari gabungan beberapa institusi besar dalam hal mewujudkan kepentingan pihak terkait, yang tentunya berporos kepada keuntungan (profit) (Adorno \& Horkheimer, 2006:42).

Adorno melihat bahwa industri budaya membuat media-media budaya seperti iklan, televisi, radio, surat kabar, majalah, film, musik, ataupun produk budaya lainnya, yang tadinya dilihat masyarakat sebagai agen informasi pencerahan keadaan, justru menjadi sebuah media yang menentukan arah serta bentuk kehidupan manusia pada saat itu ataupun masa mendatang. Hal ini tentunya tidak lepas dari pesan yang terkadung di dalam produk industri budaya yang ditujukan kepada masyarakat. Industri budaya menjadi sebuah kekuatan pengatur kontrol sosial dan masyarakat (Adorno \& Horkheimer, 2006:46), sehingga timbul hegemoni budaya pada model kehidupan manusia oleh media.

Sistem kapitalisme mewadahi media yang dikepalai oleh industri budaya menjadikan bisnis budaya sebagai bisnis ideologi dengan menciptakan produksi masal produk budaya yang mengkotakkan kehidupan masyarakat. Bisnis ini diatur oleh pihak-pihak yang memegang kekuasaan (produser media) dan ditujukan kepada konsumer media (masyarakat). Kedudukan-kedudukan pihak-pihak ini juga yang memunculkan adanya prinsip dominasi, dimana produsen dan kawankawannya berhak mengatur konsep budaya yang akan diterima oleh konsumen. (Adorno \& Horkheimer, 2006:51).

Fenomena ini tentunya terlihat dari pesan yang terkandung di dalam sebuah iklan yang ditujukan kepada masyarakat. Secara kasat mata, iklan dilihat hanya sebagai media promosi dalam memperkenalkan hingga melariskan barang dagangan. Namun, jika dilihat lebih dalam, iklan yang mengandung banyak kode budaya, berdiri sebagai pembentuk standarisasi masyarakat, yang secara tidak sengaja memaksa audience-nya untuk mau mengkonsumsi simbol-simbol yang ditawarkan demi memenuhi bentuk kenormalan dalam sebuah kehidupan.

\subsection{Stereotype oleh Richard Dyer}

Richard Dyer melihat bahwa stereotype hadir sebagai proses pembuatan jenis manusia yang diiringi dengan proses pemberhentian gagasan, generalisasi sistem kehidupan, serta penciptaan standar nilai baik dan buruk yang didukung dengan kehadiran media sebagai alat pendistribusian pesan (Dyer, 2006:353-354). Melalui kode-kode yang dibuat oleh produsen pesan, stereotype mengkotakkan kelompok masyarakat menjadi berbagai macam ukuran seperti baik atau buruk, normal atau tidak normal, feminist atau maskulin, dan sebagainya (Dyer, 2006:357-358). Stereotype dengan 
otomatis mempengaruhi fungsi serta tugas yang dimiliki oleh masyarakatnya melalui kelompok-kelompok masyarakat (Dyer, 2006:359).

\section{Kelanggengan stereotype} bergantung kepada suara dominan yang berkembang di masyarakat. Media sebagai salah satu alat pelanggeng stereotype sangat berperan aktif dalam menaikkan ataupun menjatuhkan bentuk stereotype di masyarakat, setelah pengetahuan masyarakat yang bersumber dari agama, pendidikan, budaya, ras, dan lainnya. Semakin memiliki dukungan suara dan disetujui oleh masyarakat, maka akan semakin paten stereotype yang berlaku. Dampaknya, masyarakat berbondongbondong mengkonsumsi simbol-simbol yang disyaratkan oleh sebuah stereotype demi dapat hidup dengan label "normal". Bagi mereka yang tidak mampu mengkonsumsi simbol-simbol stereotype yang berlaku di masyarakatnya, tentunya akan terasingkan atau bahwa mengasingkan dirinya sendiri dari masyarakatnya.

\subsection{Simulasi oleh Jean Baudrillard}

Baudrillard melihat bahwa saat ini tidak ada kehidupan yang benar dan asli, karena semua itu hanya berupa simulasi. Media sebagai produsen bentuk simulasi berperan aktif dalam mendistribusikan bentuk-bentuk tersebut kepada masyarakat, tentunya menggunakan proses encoding-decoding, dan membentuk suatu generalisasi terhadap kehidupan. Media membuat simulasi yang mereka produksi untuk dapat dilihat bagi masyarakat yang menerimanya sebagai suatu keaslian, kebenaran, realitas yang sebenarnya terjadi pada masyarakat. Sehingga masyarakat melihat simulasi yang ada sebagai kebenaran kehidupan yang patut dipercayai dan ditiru (Baudrillard, 2006: 453-457).

Baudrillard menarik pandangannya mengenai dunia simulasi ini ke dalam proses konsumsi masyarakat. la melihat bahwa saat ini, praktik konsumsi dijadikan sebagai poros penilaian kehidupan dan tatanan sosial. Produk media, salah satunya iklan, disajikan oleh media dengan tujuan mengambil alih peran dalam hal pembentukan norma dan aturan di masyarakat dan kemudian mengalihkan standariasi hedonistik sebagai poros sebuah kesenangan kehidupan, sehingga bergeserlah nilai-nilai kebenaran yang dahulunya dicetuskan oleh pengalaman, namun kini sederhana muncul dari sebuah simbol yang dibawakan oleh media. Inilah yang disebut sebagai hyperealitas. Dimana batasan antara kebenaran dengan simulasi telah musnah (Baudrillard, 2006:60-61).

Sebagai salah satu produk media, iklan dijadikan bahan pembuatan simulasi dimana masyarakat dipaksa mempercayai bahwa apa yang dibawakan oleh media adalah benar, sehingga ketika masyarakat ingin memiliki kehidupan yang normal dan 


\section{CAPTURE}

benar, mereka harus memenuhi bentuk simulasi yang dibawakan oleh media tersebut.

\subsection{Kapitalisme oleh Karl Marx}

Karl Marx begitu tertarik dalam melihat bagaimana sebuah ideologi mempengaruhi kekuasaan serta kedudukan yang kemudian ia sandingkan dengan industri budaya dan praktik kapitalisme. Marx beranggapan bahwa ideologi digunakan oleh kelas penguasa dalam melanggengkan serta mengamankan kekuasaannya (Strinati, 2003:149). Dalam German Ideology yang pertama kali diterbitkan pada tahun 1845/1846, Max melihat kekuasaan dalam sebuah struktur kelas sosial, memiliki kekuatan material dan intelektual, sehingga mampu memproduksi gagasan-gagasan yang menjadi aturan kehidupan masyarakat (Marx, 1963:93). Gagasangagasan inilah yang diproduksi melalui industri budaya untuk dijadikan budaya massa dan dikonsumsi oleh masyarakatnya (masyarakat kapitalis). Semakin banyak masyarakat yang mengkonsumsi produk budaya dan mengiya-kan gagasan yang dibuat oleh kelas penguasa, maka akan semakin berjayalah kelas-kelas pengusaha tersebut.

Terdapat tiga proporsi empiris yang melatar belakangi pemikiran Marx mengenai kekuasaan kelas sosial, yaitu: produksi dan distribusi gagasan dipusatkan di tangan para pemilik sarana-sarana produksi kapitalis; gagasan-gagasan yang diberlakukan akan semakin mengemuka dan mendominasi pemikiran kelompokkelompok subordinat; dominasi ideologis berfungsi sebagai pertahanan sistem ketidak setaraan kelas yang umum, sehingga memberikan hak istimewa kelas pengusaha dan mengeksploitasi kelaskelas subordinat (Strinati, 2003:150). Ketiga proposi ini mendorong Marx untuk melihat bahwa cara kerja kekuasaan kelas sosial ini dipraktikan melalui industri budaya massa. Kelas penguasa menanamkan sistem konsumsi pada masyarakat sehingga mendorong mereka memproduksi dirinya secara material, dan alhasil menjadikan diri mereka sebagai bahan eksploitasi relasi kelas (Strinati, 2003:51).

Sebagai agen produksi gagasan massa, kelas penguasa mendorong masyarakat untuk mengkonsumsi simbolsimbol yang telah mereka produksi, sebagai praktik penyetaraan diri masyarakat terhadap suatu kelas yang ditetapkan. Ketika seseorang ingin membangun indentitas dirinya kepada identitas suatu kelas, maka wajib untuknya mengkonsumsi simbol-simbol yang telah diproduksi oleh kelas pengusaha tersebut. Keuntungan profitlah yang tentunya diharapkan oleh kelas-kelas penguasa yang bertahta. Siapa yang berkuasa, maka ia lah yang berkah dalam menentukan simbol, idologi, serta gagasan yang 
berlaku.

Dalam media, produser mencoba untuk melanggengkan ideologi serta gagasan yang mereka yakini melalui pesan yang terkandung dalam video iklan. Seperti halnya video iklan Buavita, penulis berhipotesa bahwa produser mencoba melanggengkan konsep hidup sehat serta tubuh ideal sempurna bagi perempuan dan laki-laki yang dibentuk melalui pesanpesan (simbol) dalam video iklan, yang bertujuan untuk menarik audience dalam menyetarakan diri mereka terhadap ideologi tersebut. Tentunya dengan cara mengkonsumsi produk industri yang ditawarkan dan mendatangkan keuntungan profit pada pihak produsen video iklan.

\section{METODE}

Dalam penelitian video iklan Buavita, penulis menggunakan metode penelitian deskriptif kualitatif dengan empat teori kajian budaya yaitu industri budaya oleh Max Horkheimer dan Theodor W. Adorno, stereotype oleh Richard Dyer, simulasi oleh Jean Baudrillard, dan kapitalisme oleh Karl Marx. Keempat pendekatan tersebut digunakan untuk menganalisa data melalui kaca mata kajian budaya dan mampu menemukan simbolsimbol yang terkandung dalam video iklan Buavita. Objek penelitian meliputi video iklan Buavita Mix Berries, Buavita Kelapa, Buavita Mangga, dan Buavita Jambu.

Langkah pertama yang dilakukan adalah menentukan video iklan yang dipilih.
Video iklan Buavita dipilih karena ditemukannya penayangan video iklan Buavita dengan berbagai variant yang cukup sering di televisi. Video iklan Buavita juga dipilih karena menggunakan berbagai macam gender model beserta kemajemukan usia model yang digunakan. Yaitu laki-laki, perempuan, anak-anak, dan orang dewasa. Video iklan Buavita yang dipilih telah ditayangkan pada beberapa tahun yang berbeda, yaitu 2012, 2013, dan 2015. Pemilihan video iklan-iklan tersebut di lakukan secara acak untuk membuktikan adanya kemonotonan aturan gender (gender inequality dan traditional gender role) sebagai tujuan dari penelitian.

Penelitian dilakukan kurang lebih selama satu bulan mulai dari pengumpulan data, pengolahan data, hingga pembuatan laporan hasil penelitian. Data penelitian bersumber dari Youtube yang langsung didapatkan tanpa adanya pemotongan atau penambahan tayangan video iklan. Pengumpulan data dihentikan ketika dirasa data yang ada telah mencukupi.

Pengolahan data selanjutnya dilakukan dengan metode kualitatif deskriptif dan penggunaan teori industri budaya, stereotype, simulasi, dan kapitalis dengan kaca mata pandang kajian budaya. Metode dan teori tersebut digunakan dengan tujuan menemukan simbol-simbol yang terkandung dalam video iklan Buavita yang dipandang sebagai pembangun simulasi standar hidup sehat. Selain 


\section{CAPTURE}

daripada itu, penggunaan metode dan teori tersebut juga ditujukan untuk melihat aturan stereotyping antara laki-laki dan perempuan di Indonesia berdasarkan perbedaan varian Buavita yang harus dikonsumsi.

\section{PEMBAHASAN}

Pembahasan penelitian terbagi ke dalam dua fokus, yaitu temuan simbolsimbol yang terkandung dalam kalimat dan tayangan pada video iklan Buavita yang dipandang sebagai pembangun simulasi standar hidup sehat ala video iklan Buavita dan temuan aturan stereotyping antara lakilaki dan perempuan Indonesia berdasarkan perbedaan varian Buavita yang harus dikonsumsi.

\subsection{Simulasi dan Standarisasi Hidup Sehat ala Video Iklan Buavita}

\subsubsection{Simulasi dan Standarisasi Hidup} Sehat melalui Kalimat Video Iklan Buavita

$\begin{array}{rrr}\text { Video } & \text { iklan } & \text { Buavita } \\ \text { menggunakan } & \text { kalimat } & \text { pendukung }\end{array}$
sebagai penjelas atas ideologi dan juga sugesti yang produser sampaikan kepada audience. Sugesti tersebut yang penulis lihat sebagai media penanam simulasi dan standarisasi hidup sehat bagi penonton video iklan tersebut. Berikut ini penjelasan atas beberapa cuplikan kalimat yang digunakan pada beberapa video iklan Buavita.

\section{A. Kalimat Video Iklan Buavita Mix Berries}

Cuplikan kalimat pada video iklan Buavita Mix Berries: "Pencernaan baik itu awal dari banyak hal baik, campuran unik lima buah berry yang mengandung serat pangan inulin jaga fungsi saluran cerna mu. Pengen kaya saya?, gaya hidup sehat, dan minum Buavita Mix Berries setiap hari". Pada kalimat pertama yang dikeluarkan oleh video iklan Buavita Mix Berries, produsen video iklan menegaskan bahwa setiap manusia membutuhkan pencernaan yang baik sebagai awal dalam memiliki segala yang hal baik. Salah satu cara yang dapat ditempuh untuk memiliki pencernaan yang baik adalah dengan mengkonsumsi beberapa jenis buah berry yang mengandung serat pangan inulin dan mampu menjaga fungsi saluran cerna manusia.

Pada sisi ini, produsen Buavita membantu menginformasikan kepada masyarakat Indonesia bahwa mereka bisa mendapatkan serat pangan inulin melalui kandungan buah berry yang ada pada Buavita Mix Berries. Informasi dan ajakan ini tentunya ditujukan untuk mendorong para audience video iklan agar mau mengkonsumsi Buavita Mix Berries dengan tujuan menjaga pencernaannya dan mendapatkan segala kebaikan dalam hidupnya.

Tidak sesederhana itu, video iklan 
Vol.10 No.2 Juli 2019

Buavita Mix Berries secara otomatis membentuk standarisasi tubuh sehat yaitu mereka yang memiliki saluran pencernaan baik. Mereka yang tidak memiliki saluran pencernaan yang baik dikategorikan oleh video iklan ini sebagai tubuh yang tidak sehat. Standarisasi hidup sehat juga dibentuk sebagai hidup yang pada tiap-tiap harinya mengkonsumsi beberapa jenis buah berry. Bagi mereka yang tidak mengkonsumsi beberapa jenis buah berry, maka dapat dikatakan tidak memiliki saluran pencernaan yang baik dikarenakan tidak mengkonsumsi serta pangan inulin yang mampu menjaga kesehatan sistem pencernaan. Inilah yang disebut Baudrillard sebagai sebuah simulasi, dimana media membuat simulasi yang mereka produksi untuk dapat dilihat bagi masyarakat yang menerimanya sebagai suatu keaslian, kebenaran, realitas yang sebenarnya terjadi pada masyarakat, sehingga masyarakat melihat simulasi yang ada sebagai kebenaran kehidupan yang patut dipercayai dan ditiru (Baudrillard, 2006:453-457).

Faktanya, serat pangan inulin tidak hanya dapat diperoleh melalui buah berry, namun juga bawang merah, bawang daun, bawang putih, asparagus, pisang, dan gandum (Setiawan, 2017). Jenis-jenis sayuran tersebut tentunya lebih mudah ditemukan pada makanan sehari-hari. Justru, Buavita tidak memiliki varian rasa yang mengandung nutrisi dan vitamin dari bawang merah, bawang daun, bawang putih, asparagus, pisang dan gandum. Maka dari itu, dapat dikatakan bahwa video iklan Buavita Mix Berries hanyalah alat yang digunakan oleh produser dalam membentuk standarisasi dan simulasi sebuah gaya hidup sehat menurut Buavita, yang ditujukan untuk mempromosikan produknya dan bertujuan dalam pemerolehan profit. Bahkan, tanpa disadari oleh masyarakat, Buavita justru membatasi jenis makanan yang akan dikonsumsi oleh audience untuk mendapatkan serat pangan inulin karena hanya menggunakan satu jenis buah, yaitu berry. Fakta ini seperti yang dijelaskan oleh Dyer bahwa produsen pesan (iklan) mencoba membangun kode-kode yang ditujukan sebagai alat stereotyping, guna mengkotakkan masyarakat Indonesia (audience iklan) menjadi ukuran seperti yang dikehendaki oleh produsennya (baik atau buruk, sehat atau tidak sehat, normal atau tidak normal, feminist atau maskulin, dan sebagainya) (Dyer, 2006:357-358). Pengkotakkan masyarakat, pemandekan ideologi, serta penipuan massa inilah yang disebut Adorno dan Hokheimer bahwasanya informasi dari media hanya sebuah pembodohan massa (Enlightenment as Mass Decepetion) (Adorno \& Horkheimer, 2006:42). 


\section{CAPTURE}

\section{B. Kalimat Video iklan Buavita Kelapa}

Cuplikan kalimat pada video iklan

Buavita Kelapa: "Jangan nyerah nak, nih biar semangat. Minum air kelapa segar multi manfaat dan mengandung vitamin B3 dari Buavita Kelapa baru setiap hari, bantu segarkan tekad dan usahamu meraih cita-cita dan lebih lagi". Di dalam video iklan kedua yaitu Buavita Kelapa, dikatakan bahwa air kelapa mengandung multi manfaat dan vitamin B3 yang membantu memberikan kesegaran dan semangat. Video iklan ini menegaskan bahwa vitamin dan manfaat yang terkandung dalam buah kelapa dapat membantu setiap orang yang meminumnya untuk memiliki semangat tinggi dan mampu meraih cita-cita yang mereka impikan.

Faktanya, vitamin B3 tidak hanya terkandung pada buah kelapa, melainkan buah mangga, sayur asparagus, kacang-kacangan serta bijibijian, jamur, ikan tuna, ikan salmon, daging sapi, dada ayam, daging rusa, hati domba, telur dan susu. Manusia yang telah mengkonsumsi salah satu jenis makanan di atas, secara otomatis akan mendapatkan vitamin B3 dan kesegaran tubuh, meskipun tidak mengkonsumsi Buavita Kelapa. Hal ini membuktikan bahwa kembali Buavita mencoba membentuk standarisasi serta simulasi hidup sehat dengan kode vitamin B3 dan buah kelapa untuk mendorong audience-nya mengkonsumsi Buavita Kelapa.

Ketika simulasi hidup sehat dibentuk, masyarakat akan lebih percaya terhadap wacana yang dibawakan oleh media daripada fakta asli yang tidak mereka ketahui, sehingga bergeserlah nilai-nilai kebenaran yang dahulunya dihasilkan dari pengalaman, namun kini dengan sederhana muncul dari sebuah simbol yang dibawakan oleh media. Inilah yang disebut sebagai hyperealitas. Batasan antara kebenaran dengan simulasi telah musnah (Baudrillard, 2006: 60-61).

Praktik pembodohan massa melalui media lagi-lagi dilakukan oleh video iklan Buavita. Video iklan Buavita hadir seakan-akan sebagai pemenuh kebutuhan masyarakat akan vitamin B3. Tetapi kenyataannya adalah penemuhan vitamin ini mendorong masyarakat untuk hanya mengkonsumsi Buavita Kelapa, bukan buah dan sayur pada jenis lainnya. Inilah yang disebut sebagai pembodohan cara hidup masyarakat yang berkembang dalam media seperti yang dijelaskan oleh Adorno dan Hokheimer, bahwasanya perkembangan teknologi serta citra industri budaya yang hadir sebagai pemenuh kebutuhan masyarakat dan sebagai media suara masyarakat hanyalah sebuah kedok media dalam menutupi tujuan sebenarnya yaitu industri (bisnis) ideologi, pemandekan ideologi masyarakat serta pembentukan paksa masyarakat yang bertujuan untuk 
Vol.10 No.2 Juli 2019

DOI: 10.33153/capture.v10i2.2243

mewujudkan kepentingan pihak terkait yang tentunya berporos kepada keuntungan (profit) (Adorno \& Horkheimer, 2006:42).

\section{Kalimat Video Iklan Buavita Mangga}

Cuplikan kalimat pada video iklan Buavita Mangga: "Kita tahu mangga itu enak, tapi karena kaya vitamin C dan potassium, mangga juga bisa bantu fikiran tetap prima. Rahasia supaya pikiran tetap prima, hidup sehat dan teratur minum Buavita Mangga. Minum Buavita setiap hari temukan 1001 manfaatnya".

Video iklan Buavita yang selama ini dilihat oleh masyarakat dalam membantu memenuhi nutrisi harian masyarakat Indonesia, justru kembali membuat pengkotakkan jenis makanan dan minuman yang harus dikonsumsi masyarakat (tidak bebas).

Pada video iklan Buavita Mangga, disebutkan bahwa buah mangga yang kaya akan vitamin $\mathrm{C}$ dan potassium dapat membantu menjaga fikiran tetap prima sehingga dapat berkonsentrasi pada pekerjaan yang kita miliki. Faktanya, potassium tidak hanya terkandung pada buah mangga saja, melainkan pada umbi-umbian, kacangkacangan, buah jeruk, yoghurt, kerangkerangan, ikan laut, susu sapi murni, pisang, telur, kacang merah, dan lainlain (Ana, 2017). Adapun vitamin C tidak hanya terkandung dalam buah mangga, melainkan buah jambu biji, blackcurrant, leci, papaya, stroberi, jeruk bali, nanas, markisa, jeruk, kiwi, sukun, belimbing, melon, alpukat, anggur hijau, pir, dan pisang (Anna, 2017).

Hal ini membuktikan bahwasanya video iklan Buavita selalu mencoba untuk membentuk sebuah pengkotakkan dalam jenis makanan dan minuman yang wajib dikonsumsi oleh masyarakat demi memenuhi kebutuhan akan vitamin tertentu untuk memiliki konsentrasi dan pikiran yang prima. Padahal, masyarakat dapat memilih berbagai jenis buah-buahan yang juga mengandung vitamin $\mathrm{C}$ dan potassium namun tidak berbentuk minuman Buavita untuk memiliki pikiran dan konsentrasi yang prima. Selain daripada itu, standarisasi tubuh sehat yang dibangun oleh Buavita adalah mereka yang memiliki pikiran yang prima dan konsentarsi yang baik, sehingga mereka yang tidak memiliki kedua kriteria tersebut dapat dikatakan sebagai tubuh yang tidak sehat. Keadaan ini telah mampu diprediksi oleh Tocqueville (1864) yang menyebutkan bahwa monopoli budaya membentuk masyarakat melanggengkan aturan generalisasi masa yang berbunyi "You are free not to think as I do, your life, your property - all that you shall keep. But from this day on you will be a stranger among us" (Tocqueville, 1864:151). Yang 


\section{CAPTURE}

berarti bahwa siapa yang tak mampu mengikuti aturan yang berlaku serta mengkonsumsi kode yang disuguhkan, maka mereka bukanlah bagian dari masyarakat tersebut. Siapa yang tidak mampu mengkonsumsi Buavita, mereka bukanlah masyarakat yang memiliki hidup dan tubuh yang sehat.

\section{Kalimat Video Iklan Buavita Jambu}

Cuplikan kalimat pada video iklan Buavita Jambu: "Ternyata, vitamin C di jambu, berperan sebagai anti-oksidan yang baik untuk pembentukan jaringan kolagen. Ingin seperti saya?, hidup sehat dan teratur minum Buavita Jambu". Video iklan ini menyatakan bahwasanya vitamin C pada jambu mampu berperan sebagai anti-oksidan yang baik dalam pembentukan jaringan kolagen. Standarisasi tubuh sehat yang dibentuk oleh video iklan ini adalah mereka yang mengkonsumsi vitamin $\mathrm{C}$ bisa mendukung pembentukan jaringan kolagen pada tubuhnya. Faktanya, antioksidan yang mampu membantu pembentukan jaringan kolagen tidak hanya terdapat dalam buah jambu, namun juga kurma, kismis, blueberry, blackberry, strawberry, raspberry, plum, jeruk, anggur merah, cherry, manggis, dan lainnya (Anita, 2017).

Video iklan Buavita juga membentuk sebuah pengkotakkan dan simulasi palsu yang memaksa audiencenya untuk mengkonsumsi Buavita Jambu demi memperoleh anti-oksidan bagi tubuhnya. Padahal, anti-oksidan dapat diperoleh meskipun tidak melalui Buavita Jambu. Hal ini yang disebut sebagai pemaksaan massa, pengkotakkan ideologi, dan pemalsuan simulasi hidup sehat. Baudrillard melihatnya bahwa sistem kapitalis yang kini menguasai seluruh aspek kehidupan manusia, salah satunya iklan, bertransformasi sebagai pengkontrol masyarakat melalui sistem, kode, serta tanda yang membangun status serta identitas manusia berdasarkan tingkat konsumsi tanda yang mereka sanggupi (Baudrillard, 2006).

\subsubsection{Simulasi dan Standarisasi Hidup Sehat melalui Tayangan Iklan \\ Selain melalui kalimat iklan, iklan} Buavita juga menggunakan tayangan video iklan sebagai alat simulasi yang menampilkan tanda-tanda sebagai aturan hidup sehat ala Buavita.

\section{A. Tayangan Video Iklan Buavita Mix Berries}

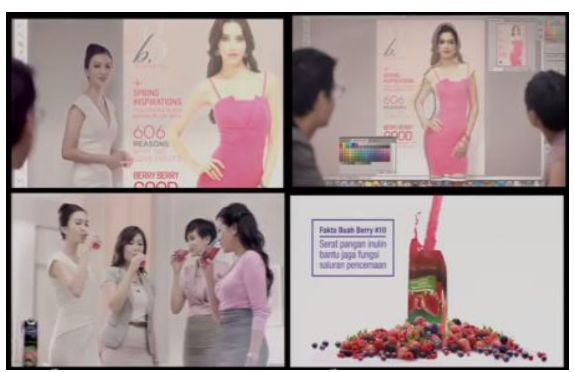

Gambar 1. Video iklan Buavita Mix Berries (Sumber: https://www.youtube.com/watch?v=QOQep V9k5BY, TC. 00:00:01-00:00:32, diunduh Asnurul NN., 23 April 2019, 21:42 WIB) 
Pada cuplikan gambar bergerak video iklan Buavita Mix Berries pada Gambar 1 dapat diketahui jika video iklan tersebut menyampaikan sebuah ideologi yang mengatakan bahwa tubuh sehat bagi perempuan adalah ketika memiliki pencernaan baik, yang dibuktikan dengan tubuh langsing ideal dan tidak buncit, yang didukung dengan mengkonsumsi Buavita Mix Berries yang mengandung serat pangan inulin. Maka dari itu, ketika perempuan tidak mampu mengkonsumi simbol-simbol yang dibawakan oleh video iklan (pencernaan lancar, tubuh langsing ideal, perut tidak buncit, mengkonsumsi serat pangan inulin) maka dapat dikatakan bahwa mereka tidaklah menjadi kelompok perempuan sehat yang memiliki pencernaan baik dan tubuh sehat yang ideal. Ini merupakan standarisasi dan simulasi hidup sehat yang dibangun oleh Buavita, yang memojokkan aundiece untuk mau mengkonsumsi produk yang mereka tawarkan demi memenuhi sebuah nilai 'wanita sehat'.

Sebagai produk industri buah, video iklan ini mengkotakkan standarisasi hidup sehat menjadi seperti standarisasi Buavita, yaitu memiliki tubuh langsing ideal, memiliki pencernaan yang baik. Selain itu, mengharuskan para perempuan ataupun audience lainnya yang melihat video iklan tersebut, untuk mengkonsumsi produk yang ditawarkan demi mencapai sebuah tujuan yaitu 'hidup sehat ala Buavita'.
Ideologi yang terkandung dalam video iklan berasal dari kelas penguasa yang berdiri sebagai produser video iklan, yang mendorong masyarakat untuk mengkonsumsi simbol-simbol yang diberikan dengan tujuan memperoleh keuntungan (profit) dalam penjualan produk. Hal ini membuat audince tidak menyadari akan gerakan pembatasan ideologi mengenai hidup sehat yang dibuat oleh para kelas penguasa tersebut.

\section{B. Tayangan Video iklan Buavita Kelapa}

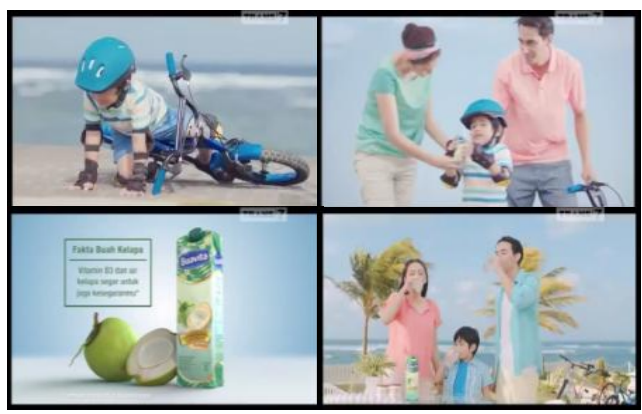

Gambar 2. Video iklan Buavita Kelapa (Sumber: https://www.youtube.com/watch? $\mathrm{v}=\mathrm{h}$ zaD8D23xg, TC: 00:00:01-00:00:30, diunduh Asnurul NN., 23 April 2019, 21:43 WIB)

Tidak jauh berbeda dengan video iklan sebelumnya, video iklan Buavita kelapa juga membentuk sebuah standarisasi hidup sehat menggunakan Buavita kelapa yang dapat membantu setiap konsumennya dalam upaya memiliki kesegaran tubuh dan membantu untuk mewujudkan cita-cita. Melalui simulasi kesehatan yang dibangun oleh video iklan ini, dapat dilihat bahwa vitamin B3 dan kesegaran diri hanya akan diperoleh melalui buah kelapa, tentunya buah kelapa 


\section{CAPTURE}

yang disuguhkan oleh produk Buavita. Standarisasi serta simulasi hidup sehat yang dibentuk oleh video iklan melalui simbol air kelapa dan vitamin B3 menyatakan bahwa bagi mereka yang tidak mampu mengkonsumsi simbol-simbol tersebut, berarti tidak akan memiliki kesehatan seperti yang video iklan Buavita paparkan.

\section{Tayangan Video iklan Buavita Jambu}

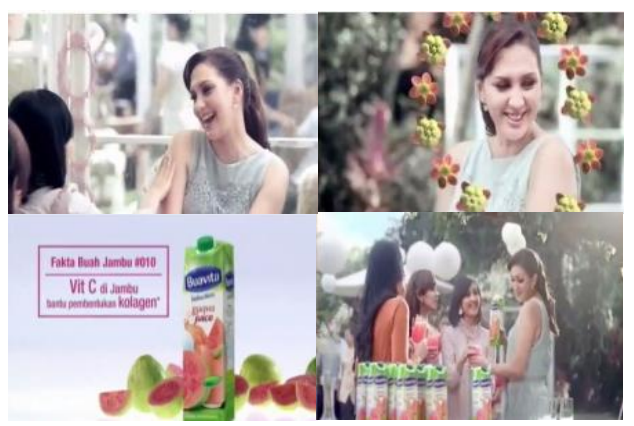

Gambar 3. Video iklan Buavita Jambu (Sumber: https://www.youtube.com/watch?v=uxJ toL1JVtY, TC: 00:00:01-00:00:14, diunduh Asnurul NN., 23 April 2019, 21:44 WIB)

Kembali sebuah standarisasi tampak pada video iklan Buavita jambu ini, dimana standarisasi hidup sehat dengan menggunakan simbol buah jambu, vitamin $C$, dan juga kolagen yang terkandung di dalam buah jambu tersebut. Melalui video iklan ini, simulasi tentang hidup sehat dibentuk dengan mendekatkan simbolsimbol yang ada, dan membuat sebuah standarisasi yang menyatakan bahwa vitamin $\mathrm{C}$ yang mampu membentuk kolagen hanya ada pada jus jambu Buavita, dan bukan pada buah lain.
Produsen Buavita mendorong audience untuk mengkonsumsi simbol-simbol tersebut jika ingin mendapatkan kesehatan kulit seperti yang dicontohkan oleh sang model video iklan. Praktik kapitalisme dan pembodohan masa ini ditujukan sebagai pemerolehan profit bagi sang produser.

\section{Tayangan Video iklan Buavita} Mangga

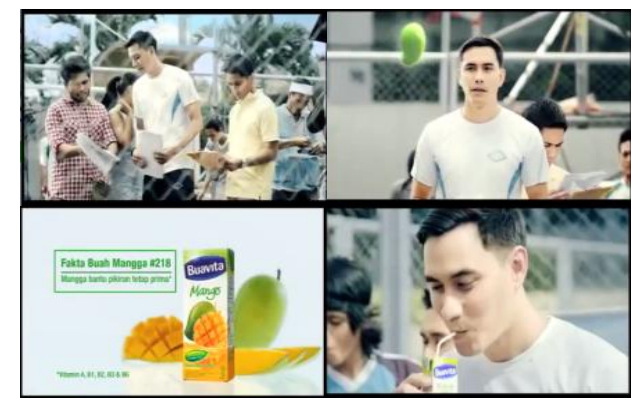

Gambar 4. Video iklan Buavita Mangga Sumber: https://www. youtube.com/watch?v=5F4zo1Znuo, TC: 00:00:01-00:00:32, diunduh Asnurul Novia Narendra, 23 April 2019, 21:45 WIB)

Video iklan terakhir yaitu Buavita mangga yang menggunakan simbol vitamin $\mathrm{C}$ dan potasium yang mampu membuat pikiran prima, membuat sebuah standarisasi bahwa pikiran prima dan konsentrasi hanya dapat diperoleh melalui jus Buavita mangga, dan bukan jus lainnya. Produser video iklan membuat simulasi hidup sehat dengan simbol-simbol yang digunakan dalam video iklan dan mendorong audience-nya untuk mengkonsumsi simbol-simbol tersebut dengan tujuan memiliki hidup sehat ala Buavita yang tidak dapat diperoleh melalui media lainnya. Penggunaan model laki-laki yang bekerja pun menegaskan manfaat 
yang dapat diperoleh oleh sang konsumen jika mengkonsumsi Buavita dan simbolsimbol yang telah disuguhkan.

\subsubsection{Video Iklan Buavita sebagai Produk Industri Budaya} Kapitalisme Pembentuk Simulasi

Pada keempat video iklan yang disuguhkan oleh Buavita di atas, penulis menemukan bahwa video iklan yang pada awalnya dilihat oleh masyarakat sebagai media informasi cara hidup sehat, justru menjadi sebuah pembodohan masa, pengkotakkan kehidupan masyarakat, pemandekan ideologi yang berkembang, pembuatan simulasi palsu hidup sehat, hingga media pemerolehan profit yang didapatkan melalui pembelian produk oleh audience.

Dalam artikelnya yang berjudul Englightenment as Mass Deception, Max Horkheimer dan Adorno menegaskan bahwa zaman pencerahan yang selalu dikaitkan dengan perkembangan teknologi serta citra industri budaya yang hadir sebagai pemenuh kebutuhan masyarakat sebagai media suara masyarakat, hanyalah sebuah kedok media dalam menutupi tujuan sebenarnya industri (bisnis) ideologi, yang terbentuk dari gabungan beberapa institusi besar dalam hal mewujudkan kepentingan pihak terkait yang tentunya berporos kepada keuntungan (profit) (Adorno \& Horkheimer, 2006:42). Hal ini persis seperti yang penulis lihat dalam pemunculan video iklan Buavita gaya hidup sehat yang hadir sebagai produk industri budaya.

Selain itu, penulis juga melihat bahwa video iklan Buavita hadir sebagai produk industri budaya dalam mendukung praktik pelanggengan konsep kapitalisme dan mendorong audience video iklan Buavita untuk mengkonsumsi simbolsimbol tubuh sehat dan hidup sehat yang disuguhkan video iklan. Penyuguhan simbol-simbol tersebut difungsikan sebagai pembuatan simulasi palsu tentang hidup sehat dan masyarakat akan lebih mempercayai fakta yang diberikan oleh media ketimbang pengalaman yang mereka miliki mengenai hidup sehat (Baudrillard, 2006:60-61), dan kebenaran hidup yang media berikan adalah kebenaran yang patut dipercayai dan ditiru (Baudrillard, 2006:453-457).

\subsection{Video Iklan Buavita sebagai Alat Pembentukan Stereotipe Gender Konsumen}

Keempat video iklan yang telah diamati, ditemukan bahwa produser video iklan tidak hanya menggunakan simbolsimbol kesehatan dalam mendorong audience untuk tertarik dan mau mengkonsumsi produk tersebut, melainkan menggunakan simbol gender yang membedakan antara Buavita bagi konsumen laki-laki dan konsumen perempuan. Simbol gender yang digunakan oleh produser video iklan disisipkan pada penggunaan tokoh atau 


\section{CAPTURE}

model video iklan.

Pada video iklan pertama Buavita Mix Berries, produser video iklan memilih untuk menggunakan model utama seorang wanita berparas cantik, bertubuh langsing dan ideal persis seperti foto model majalah yang sedang dipresentasikan oleh wanita tersebut. Dengan kata lain, Buavita Mix Berries diproduksi khusus untuk para perempuan yang ingin memiliki pencernaan sehat, tubuh langsing ideal seperti yang dimiliki oleh sang model karena mengandung serat pangan inulin yang mampu menjaga kesehatan pencernaan para wanita. Meskipun ada tokoh laki-laki dalam video iklan tersebut, namun tidak menjadi sorotan utama video iklan, tidak seperti keempat tokoh wanita lainnya. Kehadiran pemeran laki-laki hanya ditugaskan sebagai pemuji kecantikan tubuh yang dimiliki oleh model perempuan.

Video iklan kedua yaitu Buavita jambu yang juga diperankan oleh model perempuan, tampak sebagai pelanggengan stereotyping perempuan ideal yang harus memiliki kulit tubuh indah, cantik, dan rupawan yang terjaga melalui vitamin $\mathrm{C}$ yang mampu membantu pembentukan kolagen. Meskipun terdapat beberapa tokoh laki-laki pada video iklan, namun produsen tidak membuat mereka mengkonsumsi produk Buavita jambu tersebut, melainkan hanya model-model wanitanya saja. Kehadiran pemeran pria di video iklan tersebut difokuskan sebagai penguji kecantikan sang model wanita karena memiliki kulit tubuh dan wajah yang cantik karena teratur mengkonsumsi Buavita jambu. Hal ini tentunya semakin menegaskan bahwa video iklan tersebut ditujukan bagi kaum perempuan.

Sedikit berbeda dengan video iklan Buavita mix berries dan jambu, video iklan Buavita mangga menggunakan model video iklan laki-laki sebagai pemeran utamanya dan fokus kandungan vitamin C dan potasium yang dapat membantu menambah konsentrasi dan daya fikir. Produsen lebih memilih untuk menggunakan pemeran laki-laki ketimbang perempuan. Fenomena ini tampak sebagai pembentukan gender stereotyping yang menugaskan laki-laki untuk memiliki daya fikir dan konsentrasi yang baik demi memenuhi tuntutan kerjanya, dan tidak bagi perempuan.

Pada ketiga video iklan Buavita di atas, dapat dilihat adanya ketimpangan status dan kebutuhan yang dimiliki antara perempuan dan laki-laki yang dibedakan berdasarkan gender yang mereka miliki. Produsen video iklan secara sengaja membentuk status dan kebutuhan masyarakat berdasarkan gender yang mereka miliki. Ketika perempuan mengkonsumsi jus Buavita demi penampilannya yang berfokuskan pada penampilan tubuh langsing dan ideal serta kulit tubuh yang halus, laki-laki mengkonsumsi jus Buavita untuk 
mendukung mereka memiliki konsentrasi dan daya fikir yang tinggi dalam pekerjaannya. Perbedaan yang terlihat ini dapat dilihat bahwasanya produser hanya menempatkan perempuan untuk peduli dengan penampilan dan tubuh mereka (pasif, konsumtif), sedangkan laki-laki berusaha mengkonsumsi minuman sari buah demi mendukung karir yang mereka miliki (aktif, produktif). Fakta ini seperti pemikiran Modleski yang menjelaskan bahwa iklan sebagia produk budaya mencoba untuk mengsubordinasikan wanita melalui dorongan untuk memenuhi sisi femininitas, konsumsi, santai, emosi, dan pasif (Strinati, 2003:219). Hal sebaliknya yang berupa maskulin, produksi, rasional, dan aktif dibebankan pada sisi laki-laki.

Pada pembentukan stereotyping, maka terbentuk pula status dan tuga-tugas yang dimiliki. Wanita yang dibentuk melalui status femininitas, konsumsi, santai, emosi, dan pasif, diberikan tugas yang berupa sangat dekat dengan kecantikan dan domestik. Sedangkan laki-laki yang berstatus maskulin, produktif, rasional, dan aktif sangat dekat dengan pekerjaan dan wilayah non-domestik. Jika video iklan Buavita Mix Berries dan Jambu telah mampu mendekatkan perempuan pada konsep kehidupan wanita yang selalu bergulat dengan sisi kecantikan, lain halnya dengan video iklan Buavita Kelapa yang mendekatkan sosok perempuan pada sisi domestik, keibuan, istri, dan pendamping.

Pada video iklan Buavita Kelapa, perempuan ditempatkan sebagai ibu dan istri yang membawakan Buavita Kelapa kepada suami dan anaknya yang sedang belajar menaiki sepeda. Sedangkan sang laki-laki ditempatkan sebagai sang ayah yang mengajari anaknya bersepeda. Kedua perbedaan profesi yang dimiliki oleh lakilaki dan perempuan ini dapat dilihat bahwasanya wanita ditempatkan pada area domestik yang pasif, sedangkan laki-laki ditempatkan pada area produktif yang aktif. Fenomena ini dilihat oleh Richard Dyer sebagai pembentukan stereotype, sebagai proses pembuatan jenis manusia yang diiringi dengan proses pengkotakkan status, pemberhentian gagasan, generalisasi sistem kehidupan, serta penciptaan standar nilai baik dan buruk yang didukung dengan kehadiran media sebagai alat pendistribusian pesan (Dyer, 2006:353-354). Melalui kode-kode yang dibuat oleh produsen pesan, stereotype mengkotakkan kelompok masyarakat menjadi berbagai macam ukuran seperti baik atau buruk, normal atau tidak normal, feminist atau maskulin, aktif atau pasif, produktif atau konsumtif, dan sebagainya (Dyer, 2006:357-358). Dengan membuat kelompok-kelompok masyarakat, stereotype dengan otomatis mempengaruhi fungsi dan tugas yang dimiliki oleh induvidu sang pemegang status tersebut (Dyer, 2006:359). 
Praktik pembentukan stereotyping antara laki-laki dan perempuan pada video iklan Buavita ini semata-mata tidak lepas dari kontribusi media yang membuat iklan sebagai produk industri budaya, membuat media informasi menjadi sebuah media penggeneralisasi dan pengontrolan masa (Adorno \& Horkheimer, 2006:46), penciptaan status, fungsi serta tugas yang dimiliki oleh masyarakatnya (Dyer, 2006:359), pembuatan simulasi kehidupan palsu yang mendorong masyarakat untuk mendambakan kebutuhan palsu yang lebih dipercaya kebenarannya (Baudrillard, 2006: 453-457), demi pendapatan profit oleh produser (Adorno \& Horkheimer, 2006:42) yang akan melanggengkan suara kelas penguasa (Strinati, 2003:149).

\section{SIMPULAN}

Penelitian berhasil

membuktikan adanya simbol-simbol yang terkandung dalam kalimat dan tayangan pada video iklan Buavita yang dipandang sebagai praktik pembangunan simulasi standar hidup sehat ala video iklan Buavita seperti dorongan mengkonsumsi jenis buah tertentu yang menjadi varian Buavita.

(2) Sebagai media pembentuk simulasi, video iklan Buavita terbukti menjadi media pembodohan masa yang justru membatasi masyarakat untuk hanya mengkonsumsi jenis buah dan sayuran tertentu yang ada dalam varian Buavita dan melupakan buah dan sayuran lainnya yang sebenarnya mampu memberikan vitamin dan mineral yang justru lebih banyak dan lebih dibutuhkan oleh tubuh namun tidak terdapat pada varian Buavita.

Penelitian

berhasil membuktikan adanya upaya melanggengkan praktik gender inequality melalui pembentukan gender stereotype masyarakat dengan menyudutkan perempuan hanya untuk mengkonsumsi varian Buavita yang berfokus kepada tubuh dan penampilan, sedangkan laki-laki kepada kebutuhan otak dan etos kerja. Dengan kata lain, video iklan Buavita masih melanggengkan prinsip traditional gender role yang menempatkan perempuan sebagai pihak domestik dan pasif sedangkan laki-laki sebagai pihak publik dan aktif.

(4) Video iklan Buavita yang berjudul pemberian informasi mengenai cara hidup sehat justru terbukti mendorong masyarakat untuk hanya mengkonsumsi simbol-simbol tertentu yang mengkotakkan mereka kepada satu jenis masyarakat, yaitu masyarakat sehat ala Buavita.

(5) Saran dan masukan bagi penelitian selanjutnya adalah ada baiknya untuk meneliti video iklan Buavita di tahuntahun terbaru (2018 dan 2019) untuk melihat ada tidaknya perubahan konsep dan aturan gender yang terkandung dalam video iklan. Penelitian selanjutnya mungkin juga akan lebih baik untuk memadukan video iklan Buavita dengan video iklan minuman merk lainnya untuk melihat 
fenomena penanaman aturan gender pada masyarakat Indonesia melalui pesan video iklan minuman di Indonesia.

\section{DAFTAR ACUAN}

Buku:

Adorno, T. W., \& Horkheimer, M. 2006. The Culture Industry: Enlightenment as Mass Deception. In M. G. Durham, \& D. M. Kellner, Media and Cultural Studies Keyworks (pp. 41-72). Malden: Blackwell.

Anita. 2017. 11 "Buah Antioksidan Terbaik". Retrieved December 25, 2017, from Anita's Personal Blog: http://anitanet.staff.ipb.ac.id/artikelarticle/kesehatan/10-buahantioksidan-terbaik/

Anna. 2017. "Halo Sehat". Retrieved December 25, 2017, from HaloSehat:

https://halosehat.com/gizinutrisi/panduan-gizi/21-buah-yangmengandung-vitamin-c-supertinggi-dan-manfaatnya

Baudrillard, J. 2006. The Precession of Simulacra. In M. G. Durham, \& D. M. Kellner, Media and Cultural Studies Keywork (pp. 453-481). Malden: Blackwell.

Dyer, R. 2006. Stereotyping. In M. G. Durham, \& D. M. Kellner, Media and Cultural Studies Keywork (pp. 353-365). Malden: Blackwell.

Strinati, D. 2003. Pengantar Menuju Teori Budaya Populer. Yogyakarta: Bentang Budaya.

\section{Internet:}

Ana, C. (2017, December 24). 20 "Manfaat Potasium untuk Kesehatan Tubuh". Retrieved December 25, 2017, from Manfaat.co.id: https://manfaat.co.id/manfaatpotasium
Setiawan, H. (2017, August 3). "Peran Serat Pangan Bagi Saluran Pencernaan". Retrieved December 25, 2017, from Gastroenterohepatology Corner (GHC):

http://drhardiantoong.com/articles/a rticle_detail/62/peran-seratpangan-bagi-saluran-pencernaan

Unilever. 2017. "Buavita-Brand KamiUnilever". Retrieved December 23, 2017, from Buavita: https://www.unilever.co.id/brands/o ur-brands/Buavita.html

UnileverIndonesia. 2015. "Produk Buavita". Retrieved December 23, 2017, from Buavita: http://www.Buavita.co.id/product

UnileverIndonesia. 2015. "Tentang Buavita”. Retrieved December 23, 2017, from Buavita: http://www.Buavita.co.id/ 